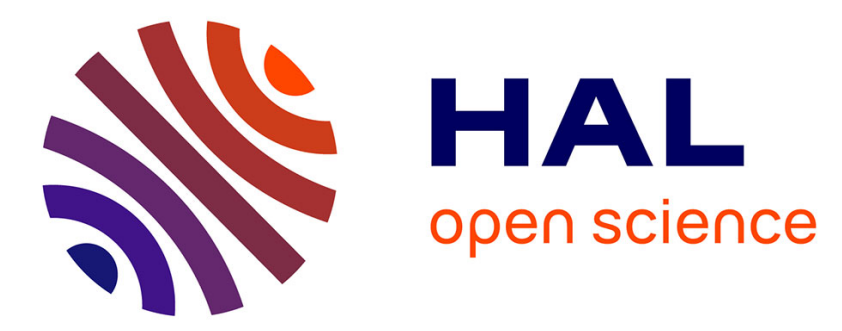

\title{
Induction of rabbit casein synthesis in organ culture by tilapia prolactin and growth hormone
}

\author{
Louis-Marie Houdebine, Susan Walker Farmer, Patrick Prunet
}

\section{To cite this version:}

Louis-Marie Houdebine, Susan Walker Farmer, Patrick Prunet. Induction of rabbit casein synthesis in organ culture by tilapia prolactin and growth hormone. General and Comparative Endocrinology, 1981, 45 (1), pp.61-65. 10.1016/0016-6480(81)90169-6 . hal-01600160

\section{HAL Id: hal-01600160 \\ https://hal.science/hal-01600160}

Submitted on 2 Jun 2020

HAL is a multi-disciplinary open access archive for the deposit and dissemination of scientific research documents, whether they are published or not. The documents may come from teaching and research institutions in France or abroad, or from public or private research centers.
L'archive ouverte pluridisciplinaire HAL, est destinée au dépôt et à la diffusion de documents scientifiques de niveau recherche, publiés ou non, émanant des établissements d'enseignement et de recherche français ou étrangers, des laboratoires publics ou privés.

\section{다(1)(2)}

Distributed under a Creative Commons Attribution - ShareAlikel 4.0 International 


\title{
Induction of Rabbit Casein Synthesis in Organ Culture by Tilapia Prolactin and Growth Hormone
}

\author{
Louis-Marie Houdebine, ${ }^{*}, 1$ Susan Walker Farmer, $\dagger$ and Patrick Prunet $\ddagger$ \\ * Laboratoire de Physiologie de la Lactation, Institut National de la Recherche Agronomique, CNRZ. \\ 78350 Jouy-en-Josas, France; †Hormone Research Laboratory, University of California, San Francisco, \\ California 94143; and $¥$ Laboratoire de Physiologie des Poissons, Campus de Beaulieu, \\ 35000 Rennes, France.
}

Accepted January 27, 1981

\begin{abstract}
Highly purified tilapia (Sarotherodon mossambicus) prolactin and growth hormone added to culture medium of rabbit mammary gland explants specifically stimulated casein synthesis. The synthesized casein was quantified by an immunoprecipitation and further identified by polyacrylamide gel electrophoresis in the presence of sodium dodecyl sulfate. In addition, the lactogenic activity of the fish hormones was determined by measuring the accumulation of $\beta$-casein mRNA using a ${ }^{3} \mathrm{H}$-labeled DNA complementary to the $\beta$-casein mRNA as a probe in a molecular hybridization. Moreover, tilapia prolactin was able to compete slightly with [125] ${ }^{25}$ prolactin for the binding to rabbit mammary gland prolactin receptor. The lactogenic activities of the tilapia prolactin and growth hormone estimated by the rabbit casein assay were about 10 and 100 times lower, respectively, than the activity of ovine prolactin, which was used as a reference.
\end{abstract}

Prolactin and growth hormone have been isolated in highly purified form from tilapia (Sarotherodon mossambicus) (Farmer et al., 1976, 1977). These hormones proved to be involved in ionic balance and growth, respectively. The criterium used for the isolation of prolactin was based on its capacity to control ionic flux in tilapia (Doneen, 1976). Unlike mammalian prolactin, tilapia prolactin was shown to be devoid of lactogenic activity as judged by a casein assay using mouse mammary organ culture (Doneen, 1976). Similarly, extracts of fish pituitaries were shown to be unable to initiate milk synthesis when added to culture medium (Nicoll et al., 1966) or when injected into rabbit (Chadwick, 1966a, b). This suggested that the activity of prolactin on ionic balance (Bern, 1975) appeared in evolution long before the lactogenic activity (Nicoll et al., 1966). In a recent report, it was shown that extracts from salmon pituitaries were capable of competing with ovine prolactin for the binding to rabbit

${ }^{1}$ To whom correspondence should be addressed. mammary gland receptor (Prunet et al., 1977). It was further demonstrated that various fractions extracted from salmon pituitaries exhibited a lactogenic activity as judged by their capacity to initiate casein and lactose synthesis in rabbit mammary gland organ culture (Prunet et al., 1979). These observations prompted us to reassess the question of the lactogenic activity of tilapia prolactin and growth hormone using the rabbit casein assay.

\section{MATERIAL AND METHODS}

Tilapia prolactin and growth hormone were fractions purified earlier (Farmer et al., 1976, 1977). Ovine prolactin was provided by the National Institute of Health (NIH-PS 13) and bovine growth hormone was from Pentex.

Rabbit mammary gland organ cultures were carried out essentially as previously described (Prunet $e t a l$.. 1979). Casein synthesis was evaluated by an immunoprecipitation of the protein synthesized for $3 \mathrm{hr}$ in the. presence of ${ }^{14} \mathrm{C}$-amino acids at the end of the cultures (Prunet et al., 1979). Triton X-100 (1\%) and sodium dodecyl sulfate $(0.5 \%)$ were added to the incubate during the immunoprecipitations to -reduce blanks (Dimitriadis, 1979). Polyacrylamide gel electrophoresis and hybridization of the $\left[{ }^{3} \mathrm{H}\right] \mathrm{cDNA}$ probe with ca- 
sein mRNA were carried out also as depicted in an earlier work (Prunet et al., 1979) with slight modifications: the cDNA probe was synthesized using partially purified rabbit $\beta$-casein mRNA instead of total casein mRNA and hybridizations were performed in $5-\mu \mathrm{l}$ incubates (Teyssot and Houdebine, 1980).

The radioreceptor assay was conducted as previously described (Prunet et al., 1977): the labeled hormone was hGH (which is inherently a prolactin) and the membrane fraction was crude microsomes extracted from the mammary gland of a lactating rabbit treated for $36 \mathrm{hr}$ with CB 154.

\section{RESULTS}

Initiation of casein synthesis. Ovine prolactin added to culture medium in the presence of insulin and cortisol exhibited a lactogenic activity as a function of its concentration (Fig. 1). The maximum activity was reached with $100 \mathrm{ng} / \mathrm{ml}$. Higher concentrations and especially $20 \mu \mathrm{g} / \mathrm{ml}$ were less efficient, an observation which may be at least partly explained by the fact that prolactin receptor is down-regulated by prolactin itself and that acute prolactin treatments reduce greatly the number of prolactin receptor, leading to a possible desensitization of the mammary cell (Djiane et al., 1979). Tilapia prolactin and growth hormone both exhibited lactogenic activity also, however, the potencies were 10 and 100 times lower than that of ovine PRL (Fig. 1). By contrast, bovine growth hormone was essentially inactive, $0.7 \%$ relative to ovine PRL.

The specificity of the immunoprecipitation technique was checked by an electrophoresis of the immunoprecipitated material on acrylamide gel in denaturing conditions. The patterns of Fig. 2 clearly indicate that the immunoprecipitates contained fractions which migrated identically with the casein marker when either ovine or tilapia prolactin, or tilapia growth hormone were present in the culture medium.

Accumulation of $\beta$-casein $m R N A$. Previous work has established that prolactin injected into rabbits or added to culture medium was responsible for an accumulation of casein mRNA in the mammary cell which roughly correlated with the rate of casein synthesis (Houdebine, 1976; Devinoy et al., 1978). Results shown in Fig. 3 indicate that tilapia prolactin and growth hormone, like ovine prolactin, induced an accumulation of $\beta$-casein mRNA in relation with their capacity to stimulate casein syn-

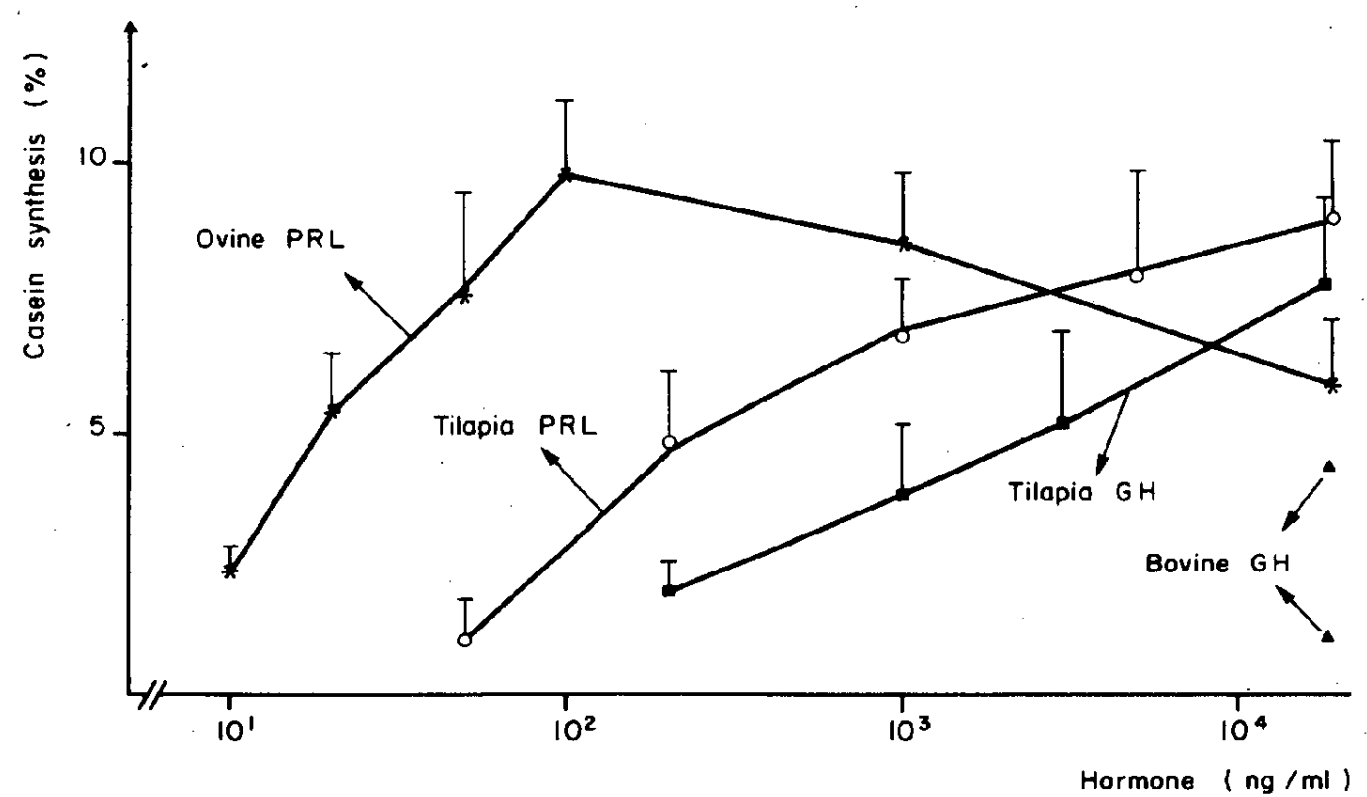

FIG. 1. Induction of casein synthesis under the influence of hormones added to culture medium. Results are expressed as the percentage of the labeled mammary proteins synthesized during the last 3 $\mathrm{hr}$ of the culture and immunoprecipitated with the anti-casein as a function of the concentration of hormones in the medium. (*) Ovine prolactin; $(O)$ tilapia prolactin; $(\mathbf{U})$ tilapia growth hormone; (A) bovine growth hormone. 


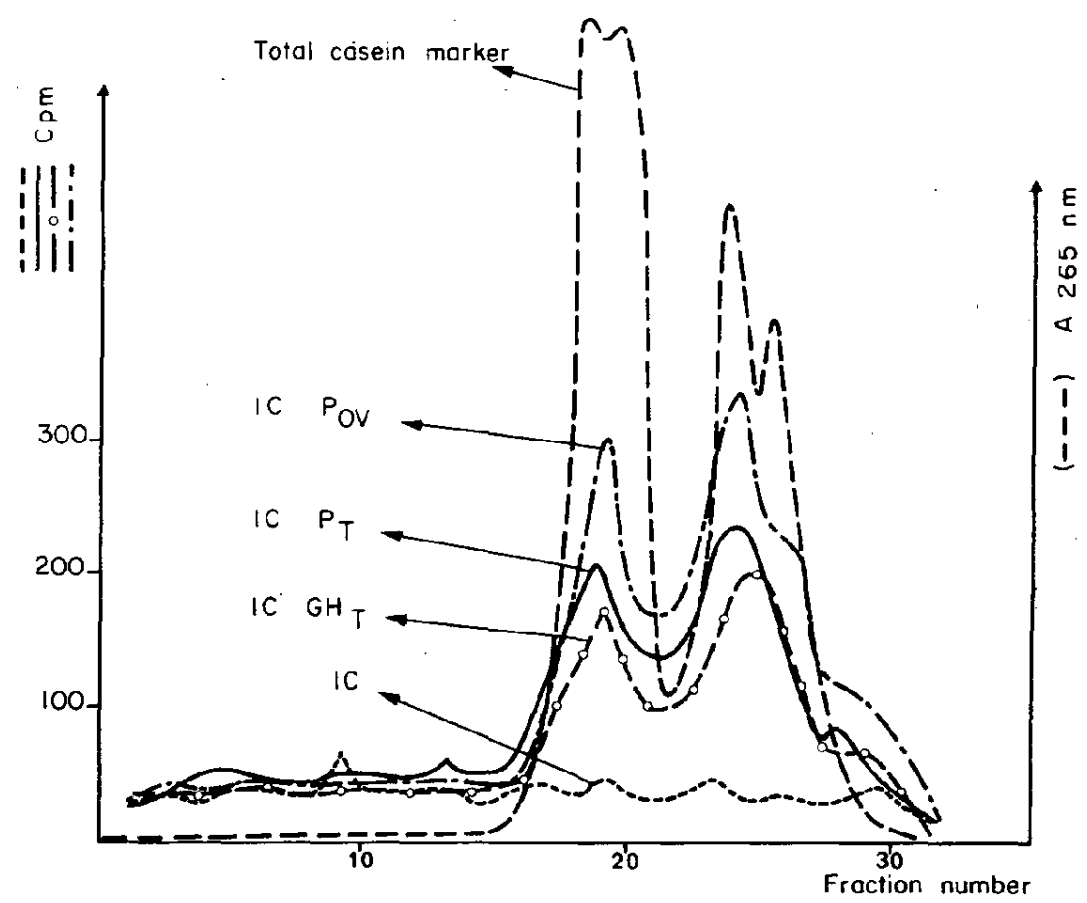

FiG. 2. Polyacrylamide gel electrophoresis of the immunoprecipitated material in the presence of sodium dodecyl sulfate. (-- ) Total rabbit casein used as marker; (- - ) ovine prolactin $(1 \mu \mathrm{g} / \mathrm{ml})$; $(-)$ tilapia prolactin $(20 \mu \mathrm{g} / \mathrm{ml}) ;\left(-\mathrm{O}_{-}\right)$tilapia growth hormone $(20 \mu \mathrm{g} / \mathrm{ml}) ;(-\cdots)$ control with insulin and cortisol only.

thesis. This further demonstrates that the fish hormones act similarly to mammalian prolactin on the mammary cell.

Binding of tilapia prolactin to rabbit mammary gland prolactin receptor. Salmon prolactin proved to compete specifically with ovine prolactin for binding to rabbit mammary gland receptors (Prunet $e t$ al., 1977). Since both tilapia and salmon prolactin have lactogenic activity, the tilapia hormone should also be able to bind to this prolactin receptor. Results shown in Fig. 4 indicate that this is indeed the case. However, the fish hormone appeared to be much less efficient that the ovine prolactin in competing with the labeled ligand. The observation that the binding of the fish hormones was not strictly related to their lactogenic activity may be due to the fact that in the radioreceptor assay, the fish prolactin was in competition with a mammalian prolactin whereas in the casein assay tilapia prolactin was acting alone. This suggests that tilapia prolactin has a lower affinity than ovine prolactin for the mammary receptor.

\section{DISCUSSION}

The data of the present report clearly indicate that tilapia prolactin is endowed with significant lactogenic activity. The fact that the salmon pituitary also contains a factor capable of inducing casein synthesis in rabbits suggests that this property might be general among teleosts and that lactogenic activity is present in the prolactin molecule earlier in evolution than previously suggested (Nicoll et al., 1966). The lower activity of the fish hormone as compared to ovine PRL may well be due to species. This finding may also suggest that full lactogenic potency of the prolactin molecule was gained only progressively.

Tilapia GH also showed significant lactogenic activity, $10 \%$ relative to tilapia PRL. By radioimmunoassay tilapia $\mathrm{GH}$ has only a $0.05 \%$ contamination with tilapia PRL (Nicoll et al., 1981). Because of this result and the high degree of purity of the tilapia GH (Farmer et al., 1976), we are convinced that the lactogenic activity is intrinsic and not due to PRL contamination. This is not a surprising finding. Growth 


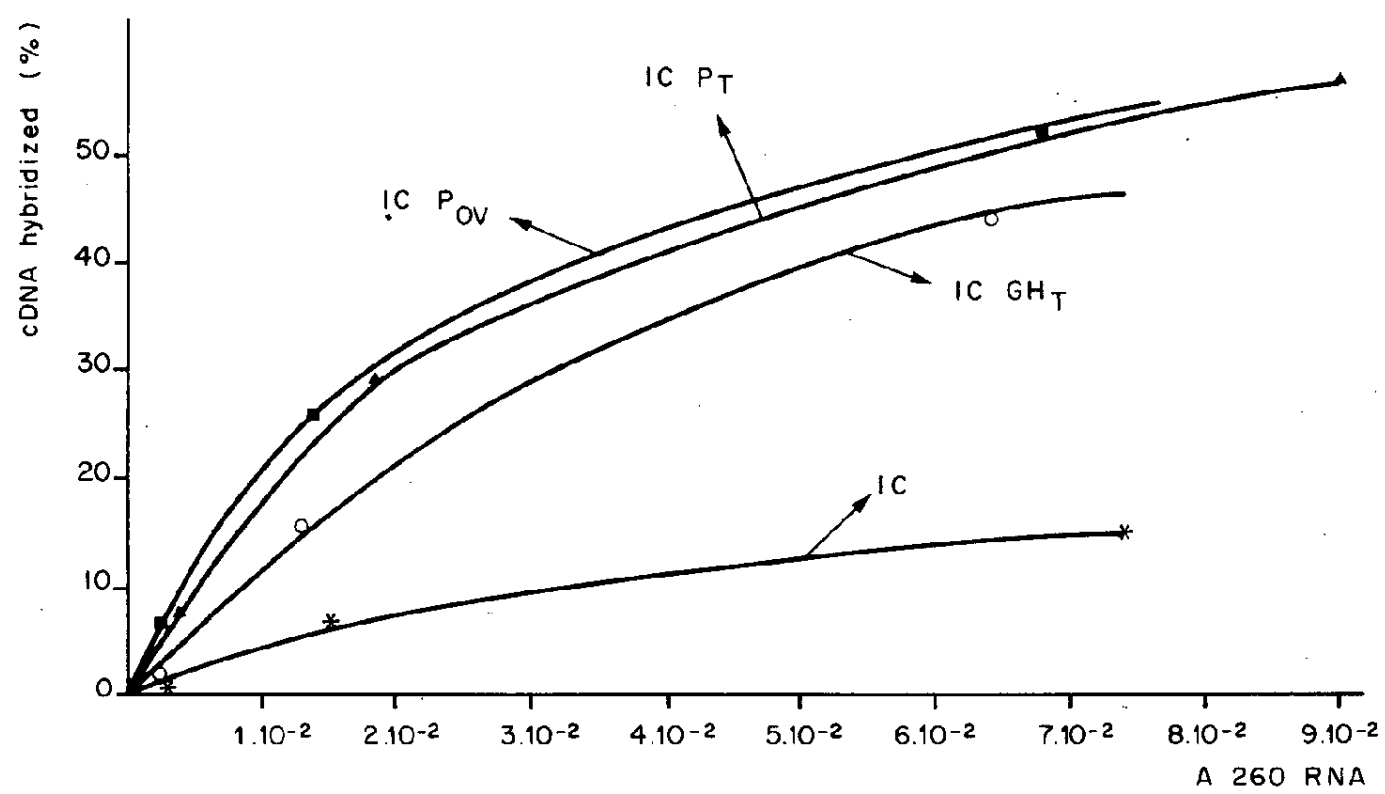

Fig. 3. Accumulation of $\beta$-casein mRNA under the influence of hormones. At the end of 24-hr cultures, total mammary nucleic acids were extracted and the $\beta$-casein mRNA concentration was evaluated by a hybridization with a labeled DNA complementary to $\beta$-casein mRNA. Results are expressed as the percentage of the cDNA in hybrid as a function of the amount of mammary nucleic acids added to the hybridization incubate. (*) Insulin + cortisol; (a) insulin + cortisol + ovine prolactin $(1 \mu \mathrm{g} / \mathrm{ml}) ;(\Delta)$ insulin + cortisol + tilapia prolactin $(20 \mu \mathrm{g} / \mathrm{ml}) ;(O)$ insulin + cortisol + tilapia growth hormone $(20 \mu \mathrm{g} / \mathrm{ml})$. The corresponding rate of casein synthesis was $0,4.46,3.6$, and $2.25 \%$, respectively (expressed as in Fig. 1).

hormone and prolactin genes are known to have a common ancestor (Cooke et al., 1980). These closely related molecules have previously been shown to have "crossintrinsic" activities, particularly when tested in distantly related heterologous as- says. Tilapia PRL showed greater crossreaction in a mammalian GH'RIA than did tilapia GH (Farmer et al., 1977). Human $\mathrm{GH}$ is well known for its intrinsic lactogenic activity.

The results reported herein are con-

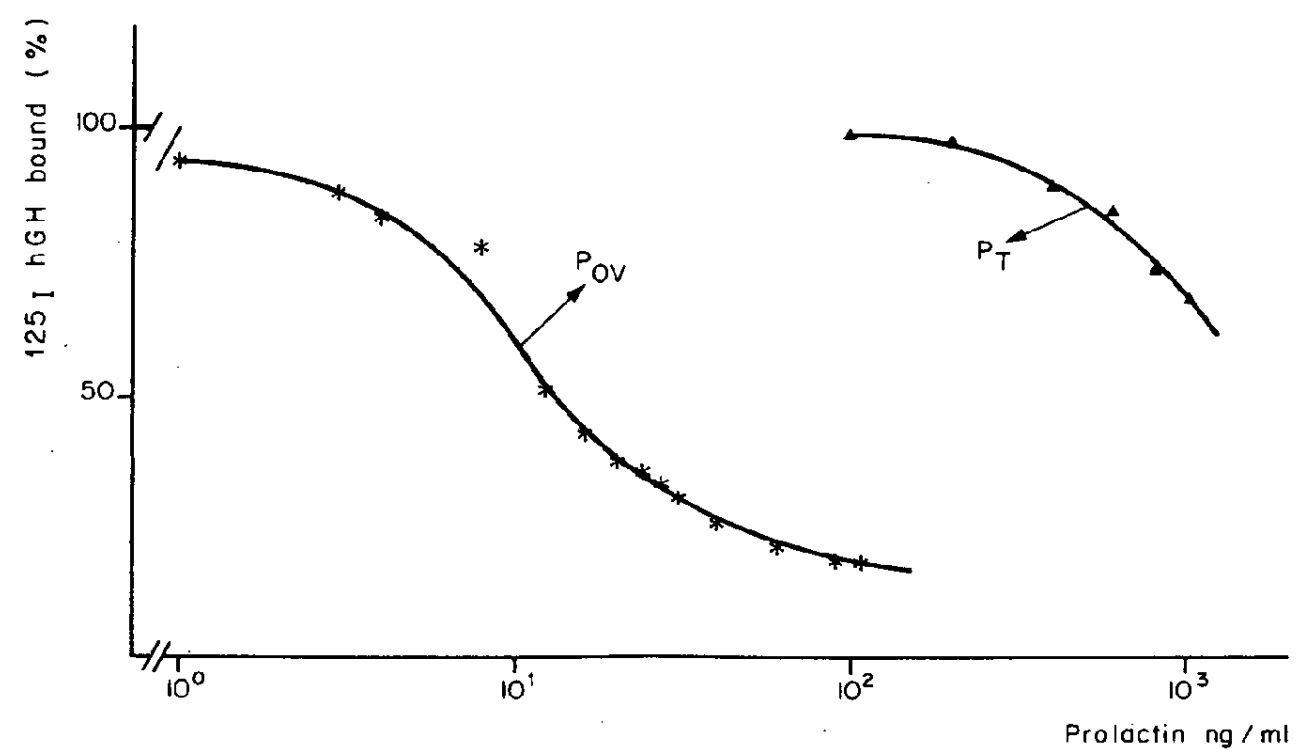

FIG. 4. Radioreceptor assay of ovine and tilapia prolactin. Rabbit mammary membranes were incubated with $\left[{ }^{125} \mathrm{I}\right] \mathrm{hGH}$ in competition with ovine polactin $(*)$ or with tilapia prolactin $(\boldsymbol{\Delta})$. Results are expressed in percentage of binding displacement as a function of the unlabeled hormones added in the incubate. 
tradictory with previous work in which it was shown that tilapia prolactin was devoid of lactogenic activity (Farmer et al., 1977). The precise reason for this discrepancy is not known. However, it should be considered that the rabbit mammary gland is known to be very sensitive to prolactin, since it can be stimulated even in the absence of glucocorticoids (Devinoy et al., 1978). The lactogenic activity of tilapia PRL may have escaped detection in the less sensitive mouse casein assay.

\section{ACKNOWLEDGMENTS}

The authors wish to thank Mrs. Claudine Puissant for her excellent technical assistance and Dr. Jean Djiane for helpful discussions. This work was supported by a National Science Foundation Grant (PCM 78-12470) to Drs. H. Papkoff and P. Licht.

\section{REFERENCES}

Bern, H. A. (1975). Prolactin and osmoregulation. Ann. Zool. 15, 937-948.

Chadwick, A. (1966a). Prolactin-like activity in the pituitary gland of the frog. J. Endocrinol. 34, $247-255$.

Chadwick, A. (1966b). Prolactin-like activity in the pituitary gland of fishes and amphibians. J. Endocrinol. 35, 75-81.

Cooke, N. E., Coit, D., Weiner, R. 1., Baxter, J. D., and Martial, J. A. (1980). Structure of cloned DNA complementary to rat prolactin messenger RNA. J. Biol. Chem. 255, 6502-6510.

Devinoy, E., Houdebine, L. M., and Delouis, C. (1978). Role of prolactin and glucocorticoids in the expression of casein genes in rabbit mammary gland organ culture. Quantification of casein mRNA. Biochim. Biophys. Acta 517, 360-366.

Dimitriadis, G. J. (1979). Effect of detergents on antibody-antigen interaction. Anal. Biochem. 98, $445-451$

Djiane, J., Kelly. P.. and Clauser, H. (1979). Rapid down-regulation of prolactin receptors in mammary gland and liver. Biochem. Biophys. Res. Commun. 90, 1371-1378.

Doneen, B. A. (1976). Biological activities of mammalian and teleostean prolactins and growth hormones on mouse mammary gland and teleost urinary bladder. Gen. Comp. Endocrinol. 30, 34-42.

Farmer, S. N., Papkoff, H., Hayashida, T., Bewley, T. A., Bern, H. A., and Li, C. H. (1976). Purification and properties of teleost growth hormone. Gen. Comp. Endocrinol. 30, 91-100.

Farmer, S. W., Papk off, H., Bewley, T. A., Hayashida, R. S., Bern, H. A., and Li, C. H. (1977). Isolation and properties of teleost prolactin. Gen. Comp. Endocrinol. 31, 60-71.

Houdebine, L. M. (1976). Effects of prolactin and progesterone on the expression of casein genes. Titration of casein $\mathrm{mRNA}$ by hybridization with complementary DNA. Eur. J. Biochem. 68, 219-225.

Nicoll, C. S., Bern, H. A., and Brown, D. (1966). Occurence of mammotrophic activity (prolactin) in the vertebrate adenohypophysis. J. Endocrinol. 34, 343-354.

Nicoll, C. S., Farmer, S. W., Nishioka, R., and Bern, H. A. (1981). Blood and pituitary prolactin levels in tilapia (Sarotherodon mossambicus; teleostei) from different salinities as measured by a homologous radioimmunoassay. Gen. Comp. Endocrinol., 44, 365-373.

Prunet, P., Djiane, J., and Breton, B. (1977). Application of radioreceptor assay for lactogenic activity to the detection of fish prolactin-like hormone. $J$. Endocrinol. 73, 391-392.

Prunet, P., Houdebine, L. M., Delouis, C., and Breton, B. (1979). Stimulation of milk synthesis in the rabbit by fish pituitary extracts. J. Endocrinol. 83, $393-400$.

Teyssot, B., and Houdebine, L. M. (1980). Role of prolactin on the transcription of $\beta$-casein and $28 S$ ribosomal RNA genes. Eur. J. Biochem. 110, $263-272$. 